\title{
FILMFHILOSOFHY
}

\section{What is the Gift of Grace? On Dogville}

Lorenzo Chiesa

University of Kent

A state of excitement takes hold of my partner / A state of excitement takes hold of his dog / A state of excitement takes hold of his belt

(Spell cast over the 'partner-candidate' of the kula by the Trobriand people)

The possibility of pursuing growth is itself subordinated to giving: the industrial development of the entire world demands of America that they lucidly grasp the necessity, for an economy such as theirs, of having a margin of profitless operations. An immense industrial network cannot be managed in the same way that one changes a tyre... [...] Woe to those who, to the very end, insist on regulating the movement that exceeds them with the narrow mind of the mechanic who changes a tyre

(Georges Bataille, The Accursed Share)

Now / You gentlemen can wipe that smile off your face / 'Cause every building in town is a flat one / This whole frickin' place will be down to the ground

(Bertolt Brecht \& Kurt Weill, Pirate Jenny)

I

The term 'grace' designates a key-notion of Christian theology. 'Grace' derives from the Latin 'gratia', which is the translation of the Greek term 'charis' as used in the New Testament. In the Bible of the Seventy, 'charis' renders in its turn a similar notion which is already present in the Old Testament in the guise of the Biblical term 'hén' / 'chén'.

In his philological review of Lars von Trier's film Dogville, Charles Baladier (2003) reminds us that this Hebrew term has three different intertwined meanings: it refers to the 
abstract favour that is awarded by a high rank personality to one of his subjects, the concrete witnessing of this benevolence on the part of the benefactor who thus fait grâce, as well as the charm that the beneficiary receives from the fact of being in the benefactor's good graces. Grace can never be attributed to just one person. The dialectical character of this notion is even more evident in the Latin term 'gratia', which can signify both generosity in giving and gratitude for having received. To put it simply, both the Biblical and the Roman pagan grace are ultimately based on a continuous exchange of favours, or gifts, in which what Marcel Mauss named the gift-exchange of primitive societies still resonates.

More precisely, Mauss describes the gift-exchange as the 'exchanges and contracts [that] take place in the form of presents [...] given and reciprocated obligatorily [...] a "total" social phenomen[on] [that gives expression to] all kinds of institutions at one and the same time - religious, juridical, moral, [...] economic' (1990, 3). From this standpoint, the whole social fabric, the symbolic order as such, however complex, is born out of and constantly relies on the gift. Jacques Lacan fully endorses this, as is shown in Seminar IV, when he relates the mythical emergence of primitive symbolisation in the child to the transformation of the virtual object into a gift. After the mother has neglected the child's appeal, objects - first of all the breast - that up to this point were, for the child, virtual objects that satisfied a biological need, are transformed into gifts that may or may not be donated by the real mother as a power. What is more, the real object of need can be perceived as such only after the child has confronted himself with a lack of object, after having realised that the object may not be donated: the relation subject-object is clearly based on the productive nature of the lack. The virtual Real precedes the Symbolic but it can be 'given' as actual only by the symbolic dimension of the gift. ${ }^{1}$

II

In Dogville, something definitely goes wrong at the level of the gift-exchange. And this for two main reasons: first, the gift of the charming fugitive named Grace (Nicole Kidman), the gift of Grace - who gives herselfaway to the townspeople, as Lars von Trier remarked in an interview $^{2}$ - is not reciprocated, or better, stops being reciprocated. As we have just seen, following Mauss, the gift, and the symbolic order it sustains, is nothing but reciprocation.

\footnotetext{
1 See Lacan (1994), especially the first five lessons.

2 'About Dogville'

Chiesa, Lorenzo (2007) 'What is the Gift of Grace? On Dogville', Film-Philosophy, vol. 11, no. 3: 
Second, the unconditional way in which Grace offers herself to Dogville is as such dangerous: the pure gift soon turns into a poison (Mauss 1990, 62-63), a dis-grace. On this point, von Trier states the following: The idea behind Grace's treatment at the hands of the townspeople was that if you present yourself to others as a gift, then that is dangerous. The power that this gives people over the individual corrupts them'. ${ }^{3}$

And yet, as Baladier cleverly suggests, it is this very excess of giving on GraceKidman's part, the fact that, at a certain stage, her unilateral favours interrupt the to-and-fro of Biblical and pre-Biblical grace as exchange, that makes of her a perfect allegory of Christian Grace. As Giorgio Agamben explains in The Time That Remains, the Maussian gift is not the Pauline grace insofar as the latter involves a real element of gratuitiousness which the former stages only in the name of 'an absolute indissolubility between the gift and obligation' (Agamben 2005, 123). Furthermore, this 'other' face of Christian Grace, one permeated with mysticism, also entails a Christ-like 'deliberate rejection of power': as Baladier has it, this 'goes as far as fostering, or at least not refusing, abjection, helplessness, humiliation, dereliction and what is called kénose - a Greek term which designates the fact that one "empties" oneself' (Baladier 2003). ${ }^{4}$

Baladier's reading of Dogville fails to account for the film's finale. How should we interpret Grace's final violent act, the extermination of all Dogvillians? Is it simply a matter of sheer revenge? In his interviews, von Trier repeatedly emphasises this element (in Lumholdt (ed.) 2003, 207): yet, at the same time, he admits that, insofar as she 'does not turn the other cheek' (in Lumholdt (ed.) 2003, 210) - or better, unlike the other female protagonists of his earlier films, she stops doing this - Grace 'has to possess a capacity for something else' (in Bjorkman (ed.) 2004, 252).

While Baladier remains strangely silent about the value we should attribute to Grace's final violence, most lay reviewers on the internet concentrate their comments on

\footnotetext{
3 'About Dogville'. According to psychoanalysis, the mother as a power capable of dispensing gifts must be able to say 'No!' if she does not want to pervert her offspring: to say this in Lacanian terms, a healthy dialectic of exchange begins with a 'dialectic of frustration'.

${ }^{4}$ In his last unfinished autobiographical novel Petrolio, Pier Paolo Pasolini captures effectively the erotic implications of such a signification of Christian grace. While developing an implicit rewriting of the Lacanian dictum 'There is no sexual relationship', he proposes that, from a 'cosmic' standpoint, being possessed by the penis and its violence is that which is furthest from Evil, or, 'is the only possible experience of Good as Grace': on the other hand, possession is, for him, by definition, 'THE Evil'. (Pasolini 1992, 319)
} 
it. The overwhelming majority of them tend to defend, if not praise, Grace's act. I think we should agree with Pisanoid, from 'somewhere in the U.S.', when he says that 'so complete is [Grace's] humiliation that the twist at the end leaves the viewer very little sympathy for the fate of Dogville's citizens'. More specifically, isn't it the case that Grace's violence is precisely that which avoids the imminent threat of an apocalypse triggered off by the detachment of the unilateral Christian gift, pure grace, from the circuit of dialectical giftexchange? In stark contrast to some readings of von Trier's film (see De Kesel 2004), I am inclined to suggest that the final massacre is precisely what stops the perverse biopolitical economy of 'the time that time takes to finish' - Agamben's definition of Messianic time and that, for this very reason, it should not be regarded as an apocalyptic revenge. GraceKidman's violent act should not be seen as an 'arrogant' Armaggedon; it is not arrogance one of the key notions of Dogville - that causes the final carnage. Quite the contrary: the carnage is the unavoidable product of the overcoming, on Grace-Kidman's part, of perverse Christian arrogance, whose more familiar name is 'forgiveness'.

IV

In Seminar VII, Lacan suggests that the discourse of science which nowadays dominates the world is engaged in an ambiguous relationship with the Thing. Although it 'repudiates the presence of the Thing insofar as from [science's] point of view the ideal of absolute knowledge is glimpsed', this same ideal is 'something that equally posits the Thing without accounting for it' (1992, 131, my translation). In other words, the mythical achievement of absolute knowledge would be perfectly equivalent to the real-isation, the demise, of the Symbolic: science 'posits the Thing without accounting for it' in the sense that the more it repudiates its presence as real lack of the symbolic order, the closer it comes to returning to the primordial Real by means of a self-saturation of the Symbolic. This is the reason why, elsewhere in Seminar VII, Lacan can rhetorically ask: 'Have we crossed the line [...] in the world in which we live?' $(1992,231)$. He believes that the possibility of the death of the Symbolic has become a tangible reality for us: one need only think of the impending threat of the atomic holocaust and 'an anarchy at the level of chromosomes' (Lacan 1992, 232).

Furthermore, the discourse of contemporary science - which 'forgets nothing by reason of its structure' and reveals for the first time the power of the signifier as such - is ideologically inextricable from what Lacan names the discourse 'of the general good' (1992, 236, my emphasis). The general good should be understood as a 'bourgeois fancy' 
(1992, 303, my translation), Lacan says, a post-revolutionary ${ }^{5}$ 'politicisation' of happiness which involves an enormous distortion of the Aristotelian service of the good: indeed, precisely insofar as it relies on the premise that 'there is no satisfaction for the individual['s desire] outside of the satisfaction of all' (Lacan 1992, 292), it is by no means compatible with Aristotle's elitist morality of the master. Here Lacan is primarily interested in showing how the epistemological paradox of the discourse of science is echoed by a simultaneous ethical paradox: 'The good cannot reign over all without an excess emerging whose consequences are fatal' (Lacan 1992, 259). We thus obtain what Lacan names 'criminal good' $(1992,240)$. In other words, the discourse of science considered as the discourse of the general - or better, potentially universal - good (Lacan 1992, 318) refuses to carry out any destruction of goods - in the widest sense of the term - 'consciously and in a controlled way'. A clear example of these practices may be recovered in the ritual ceremony of the potlatch, Lacan says, in which a variety of goods (consumer goods, luxury goods, goods for display) are destroyed as gifts in order to favour 'the maintenance of intersubjective relations' (Lacan 1992, 234-35, my emphasis). Such a refusal on the part of science makes it impossible to 'discipline' desire insofar as desire 'requires as its necessary correlative [controlled] destructions', and consequently leads to 'massive destructions' (Lacan 1992, 235).

\section{$\mathrm{V}$}

As Marcel Mauss reminds us, the potlatch was widely practiced by native Americans who lived 'between the Rocky Mountains and the [west] coast' $(1990,6)$. Interestingly enough, it is precisely in this area that the fictional US town of Dogville was later built. Taking our cue from such geographical coincidence and historical succession, aren't we entitled to associate the discourse of the general good described by Lacan, the discourse that forecloses lack and institutions such as the potlatch - and thus turns into a 'criminal good' with the discourse of the Dogvillian Thomas Edison Junior? Can't we say of Tom what Lacan says of Antigone's Creon, namely that he wants to 'promote the good of all as the law without limits, the sovereign law, the law that passes the limit' - that is, the Pauline law that 'fulfils' itself? (Lacan 1992, 259)

\footnotetext{
${ }^{5}$ See in relation to the French Revolution (Lacan 1992, 292) and in relation to the Russian Revolution (Lacan 1992, 318).
}

Chiesa, Lorenzo (2007) 'What is the Gift of Grace? On Dogville', Film-Philosophy, vol. 11, no. 3: 
No doubt Tom pursues the good. He has the best possible intentions. Right from the beginning of the film, the omniscient narrator informs us that Tom 'felt obliged to benefit the town' and organized meetings on so-called 'moral re-armament'. It is he who understands that the people of Dogville have a 'problem' with acceptance, and hence that they need something to accept, 'something tangible like a gift'. It is he who makes the first active move to initiate the dialectic of gift-exchange upon Grace's arrival. Recall the following scene: Grace and Tom have just met; Grace has stolen the bone of Dogville's dog, Moses, because she is hungry. (In passing, we should note that, at this early stage, Grace has already been animalised.) Tom offers her some bread:

GRACE: 'I don't deserve that bread; I have to punish myself; I was raised to be $\operatorname{arrogant}^{\prime 6}$

TOM: 'In this town, in these times, it's very impolite not to eat what's given you' Grace accepts Tom's intrusive initial gift since, as Mauss points out, the gift entails an obligation to accept it and to return it later. The dialectic of gift-exchange is thus started. However, Grace is clearly aware of the fact that she does not have anything to offer in return: 'No, I think you have plenty to offer Dogville', replies Tom. Grace takes Tom's words at face value and, from that moment on, she will give herself away without constraint in order to punish herself masochistically: this is Grace's supreme Christian arrogance.

Last but not least, it is again Tom who convinces Dogvillians to accept Grace, even if they do not need her. His point is that she can do everything they do not need done, a clear indication of the purely symbolic status of Grace's services. Initially, this seems to be a very enlightened argument. For a while, Grace's duties are perceived as an unnecessary surplus, which is, as such, disposable and consumable, not reducible to a logic of accumulative profit.

So why does Dogville later come to include Grace's services in an expanded economy of enterprise and sadistically demand of her always more unnecessary gifts, as if they were necessary? Chapters Three and Four of the film are said to depict a 'happy time' in Dogville: the entire community votes for Grace to remain in town; they even give her some useful gifts in case the result of the vote was not unanimous and she was compelled to leave. As the narrator says, 'Grace had friends in Dogville, that was for sure'; 'Grace had bared her throat to the town and it had responded with a great gift, with friends'. We are also told

\footnotetext{
${ }^{6}$ Grace was educated as the daughter of a Depression-era gangster, something against which she is rebelling. Grace's encounter with Dogville is caused by her attempt to rebel against her father.
} 
that 'she had left a trace' on Dogville and, conversely, that her stay in town had had a great positive impact on her. What is the reason underlying the termination of such an idyll?

One could simply argue that the major threat against the perpetuation of friendship and the gift-exchange comes from the outside: law enforcers arrive in Dogville and put up a notice; Grace becomes officially a 'missing' person. Shortly after, the police visit the town again: literally embodying the two basic characteristics of the symbolic object, Grace is now also 'wanted'. There is a reward for her capture, and Dogvillians feel they are in danger. Yet, in opposition to this interpretation, I would rather argue that the real threat to Grace, and Dogville, is an internal one: after, the first note has been affixed, it is Tom who convinces Dogvillians not to turn Grace in to the police. Grace herself does not seem to be particularly glad at Tom's impressive ability to persuade others:

GRACE: 'I think you should vote again'

TOM: 'Why? We can't resort to plebiscites all the time ${ }^{7}$

A similar dialogue takes place after the second arrival of the police:

GRACE: 'I think I should leave; enough is enough'

TOM: 'No! I suggest the opposite!'

It is Tom who wishes to keep Grace in Dogville at all costs: for him, enough is never enough... Why? First of all, because, as the narrator observes early on in the film, Grace 'fitted Tom's mission of educating Dogville for acceptance, like a glove'. Tom cares only about his 'mission', he does not care about Grace herself: his mission involves the attainment of the universal good. He is not content with the partial good Dogville has successfully achieved by following his advice. In other words, as he will admit shortly before he is killed by Grace, Tom 'uses' her, and this is his 'arrogance'.

Secondly, Tom wishes Grace to stay in Dogville because he desperately wants to 'decipher' her - to use his own words - precisely insofar as there is in Grace something that always eludes him, something that is in her more than herself. This is the reason why Tom is unable to love. Grace falls in love with him, but he does not fall in love with her. In this sense, Tom perfectly embodies the scientific discourse of the general good as that which 'repudiates' lack - 'the presence of the Thing' - in the name of absolute knowledge and, is so doing, paradoxically evokes the Thing without being able to control it. The consequences of such an evocation are truly catastrophic. In this regard, psychoanalysts

\footnotetext{
${ }^{7}$ A clear indication of the profoundly undemocratic nature of the alleged democracy of the general good...
} 
should not fail to examine Tom's magnificent slip of the tongue at the moment when Grace declares her love for him:

TOM: 'When I come to decipher you, I get absolutely nowhere'

GRACE: 'Are you trying to say you're in love with me [...] I think I'm in love with you too'

TOM: 'Very interesting... Psychological [...] They... they are calling you'

GRACE: 'I didn't hear them' [expects to be kissed]

TOM: 'You should get back anyway... See you at the wedding, hum... celebration'

The celebration in question is the $4^{\text {th }}$ of July and the citizens of Dogville who have up to now been hospitable merrily sing 'America, America God shed his Grace on thee'. But for Tom this very celebration is nothing less than a wedding, one in which he marries Grace to the cause of the general good of the American community, a good that will soon inevitably turn into a criminal good. Lacan is absolutely right: 'There is no satisfaction outside of the satisfaction of all' for those who engage in the discourse of the general good, and Tom is surely one of them. Needless to specify, this scene, quite literally the last Supper, with Grace's two betrayers sitting at her side - Tom and Chuck, the cynical idealist and the incurable fatalist; Peter and Judas, the only two Dogvillians who are left untouched by the evental gift of Grace - is immediately followed by the beginning of Grace's passion.

It is thus significant that when Grace - as she herself says - finally decides to 'solve the problem of Dogville' by way of a final massacre, she mockingly adopts Tom's very terminology. At this stage, Dogville's 'problem' has grown disproportionately. What Tom mistakenly believed to be the 'problem' of Dogville (the difficulty, but not, as is proved by the facts, the impossibility of accepting) is replaced by Tom's much more serious problem (the pursuit of the universal good). After all, Dogville's actual problem is that it follows Tom blindly just as Thebes's problem was that it followed Creon. Most importantly, we should emphasise that, in opposition to Tom, Grace painfully decides to solve the specific problem of Dogville in order to make the world a 'little better', as she says. Against all appearances, Grace's violence is limited and does not partake of the discourse of the general good.

VI

The scientific universal good for which Tom self-destructively strives has clear ethical and economic implications. His vainglorious ideals are not sufficient to account for what corrupts Dogville. As we have seen with Lacan, there is a strict connection between the 
ideological imposition of an ethics of the universal, criminal good, and the foreclosure of any 'controlled' destruction of economic goods, aimed at preserving intersubjective relations. Suffice it to recall how, in Dogville, it is Tom who proudly co-ordinates the increase-your-productivity phase of Grace's ordeal, not to mention the fact that it is he who jealously saves the Father-gangster's calling card in his drawer, and his promise of a reward together with it. Three times Grace refers to the reward, and three times Tom, like Peter, assures her that he would never betray her. Significantly enough, the first thing he says when welcoming the gangsters he himself has called is 'None of us feels well about accepting money for just helping people'. Tom understands his economically lucrative betrayal as part of the discourse of the general good. ${ }^{8}$

VII

In The Accursed Share, Georges Bataille develops his notion of 'general economy' according to which 'the "expenditure" (the "consumption") of wealth, rather than production, [is] the primary object' $(1991,9)$. General economy focuses on the global circulation of energy on Earth and thus underlies what we normally call 'economy'. Everyday economic calculations belong to a 'restrictive economy', whose principles of scarcity and utility inevitably overshadow the basic principles of general economy, namely excess and exuberance. For Bataille, this status quo is a complex and dangerous one. On the one hand, man's disregard for the material basis of his life is somehow structural: humanity sticks to the resolution of the immediate difficulties it encounters - 'a resolution which it has hastily had to define as an ideal' $(1991,21)$, Bataille specifies. On the other hand, in so doing - adopting exclusively the standpoint of restrictive economy - humanity assigns to

\footnotetext{
${ }^{8}$ The misadventures of the real Thomas Edison Junior are rather instructive with regard to those of his fictional homonym. A website dedicated to his memory (http://members.aol.com/taedisonjr/) - whose tone is very reminscent of Dogville's narrator - informs us that Junior greatly differed from his illustrious father, the supreme American inventor of the phonograph, the incandescent light bulb, and the movie camera. (Recall that Dogville opens with a discussion between Tom and his father - a respected retired doctor - that focuses on the best possible use of the radio...) A life of notoriety fuelled Junior's false feelings of magnitude: he proceeded to fabricate all kinds of outlandish ideas none of which came to fruition. In spite of his addiction to alcohol, a disastrous marriage, and the fact that his father legally prohibited him to use his surname, Junior managed to become the ostensible head of industries such as the Thomas Edison Junior Chemicals, makers of 'the Wizard Ink' medications as well as the 'Magno Electric Vitaliser', a patent cure for everything from rheumatisms to deafness. Junior also 'create[d] an improved automobile carburettor through the indulgence of family friend Henry Ford'. Unfortunately, the latter did not think much of the carburettor in question, a fact that pushed Junior back to alcoholism to the end of his days... The following dialogue from Chapter 2 of Dogville is therefore possibly more significant than it may initially appear: GRACE:
} 
the forces it employs an end which they cannot have. In other words, from the standpoint of general economy, it is necessary to lose the excess energy that cannot be used for a system's growth, but man denies this necessity. As Bataille writes: 'If the system can no longer grow, or if the excess cannot be completely absorbed in its growth, it must necessarily be lost without profit, gloriously or catastrophically' $(1991,21)$.

In terms of general economy, I think Dogville's 'problem' lies precisely in its inability to lose the excess, Grace, without pursuing profit, after it can no longer be absorbed in Dogville's growth. This has catastrophic consequences. Grace is, from the very beginning, an excess for Dogville. Grace allows the system-Dogville to grow, but when the time comes for the excess to leave the system, Dogville is persuaded by Tom that this excess is still profitable. Grace's passion is a perfect example of how a society ruled by what Bataille calls the 'economy of enterprise' is nothing other than a sado-masochistic accounting machine, vowed to self-destruction. All Dogvillians learn to become good managers. Grace's salary is first cut, then annulled. The bell rings twice an hour to regulate her labour. Vera 'counts' her anger in the number of figurines to be broken in compensation for Grace's alleged flirting with Chuck. Ben is in the 'freight industry' and a lift on his truck costs 10 dollars plus a 'surcharge for dangerous load' - i.e. consenting to be raped. The children themselves ring the bell each time there is a sexual encounter between Grace and Dogville's male population. Needless to add that Tom is the town's über-accountant. Grace's passion begins with these words of his: 'From a business perspective', that of restrictive economy, 'your presence in Dogville has become more costly'. More precisely, Tom unashamedly deploys the most obscene side of accountancy, the bureaucratic logic according to which profit lies more in counting than in sheer profit: They wanted you to work longer hours. What I proposed is that you just pay a visit to folks twice. It would seem like you're willing to contribute more without actually lengthening your day'.

On the other hand, it is interesting to observe how the 'happy' phase of growth, the establishment of friendship between Grace and Dogville, seems already to be governed by what Bataille calls 'glorious' economy. Yet, glory and growth are not incompatible in Dogville. As we have seen, everything works out well as long as Grace's duties are carburettor that doesn't leak'. 
perceived as an unnecessary surplus: she does what does not need to be done; she is positively 'expended'. This is the economic aspect of the glory of Grace.

VIII

According to Bataille, if man refuses useless consumption or loss - as he is constantly urged to do since 'separate beings [...] are nothing but eternally needy individuals' $(1991,23)-$ his refusal does not change the final outcome of general economy in the least. What is not expended gloriously, by means of man's awareness of the dynamics of general economy, is then expended 'catastrophically' through wars. Lacan makes the very same point in Seminar VII: the only real alternative that man - as being of language whose essence is desire - has is between 'conscious' destructions, that are thus 'controlled', and 'massive' uncontrolled destructions. Violence is thus necessary but, as Bataille specifies, 'it is subordinated to the concern for uniting and preserving the commonality' $(1991,59)$, for saving the community from ruination. Lacan and Bataille tacitly seem to agree on two other related issues:

1) 'Under present conditions, everything conspires to obscure the basic movement that tends to restore wealth to its function, to gift-giving, to squandering' (Bataille 1991,38 , see also 40). That is to say, in spite of the fact that history must structurally deny general economy to different degrees, capitalistic economy forecloses it tout-court. this corresponds to the passage from a neurotic to a psychotic civilisation which is accompanied by an increase of catastrophic disasters. The two World Wars are evident proof of this (see Bataille 1991, 24-25);

2) The potlatch, considered as a gift that is immediately expended, and whose destruction is often reciprocated with interest by another more generous destruction, is a fine example of a practice - and a civilisation - that is aware of the importance of general economy. As Bataille writes, 'it would be futile [...] to consider the economic aspects of potlatch without first having formulated the viewpoint defined by general economy' $(1991,68)$. In opposition to capitalism's endless accumulation - as Lacan points out in Seminar XVII, a good capitalist 'never pays', even if he spends to enjoy, he never loses - the potlatch really consumes the surplus, it enacts a consumption without counting (Bataille 1991, 59).

Bataille is also interested in the openly ethical dimension of general economy: he proposes that 'changing from the perspectives of restrictive economy to those of general economy actually accomplishes a Copernican transformation: a reversal of [...] ethics' $(1991,25)$. On 
the one hand, we could go as far as suggesting that Lacan's ethics of psychoanalysis - an ethics primarily concerned with the preservation of lack as a precondition of the symbolic order - represents an initial tentative elaboration of such a new 'general' ethics. ${ }^{9}$ On the other hand, we must nevertheless emphasise a fundamental difference in Lacan's argument, one that makes his overall stance far more convincing than Bataille's. While, for Bataille, general economy applies first and foremost to the 'living organism', for Lacan this notion relates only to symbolic constructions. Lacan is concerned with the general economy of the Symbolic. General economy is not a matter of 'energy'. Man as being of language needs to carry out useless symbolic expenditures in a controlled way in order to avoid an uncontrolled symbolic catastrophe. In saying that, according to Lacan, general economy applies exclusively to the symbolic order, I am obviously not suggesting that, for him, general economy does not have concrete effects at the level of lived everyday reality. Quite the contrary, in being necessarily symbolised, everyday reality is entirely governed by general economy. What Lacan refuses to accept is the existence of a pre-symbolic 'meaning of general economy'. ${ }^{10}$ To put it differently, general economy is solelya matter of ethics, not of biology. Contradicting Bataille on this point, we could well say that, for Lacan, 'incomprehension' of general economy on the part of man does change the final outcome (see Bataille 1991, 23). If, for Bataille, the real living organism perpetuates its existence according to the laws of general economy independently of man's decisions - what Bataille calls his 'consciousness' (1991, 40-41) - for Lacan, general economy - which is a symbolic general economy - can ultimately subsist only by means of man's singular ethical decisions concerning his desire. In other words, for Lacan, the symbolic order does not regulate itself automatically, and, for this reason, can even wipe itself out.

IX

In The Accursed Share, Bataille naively assumes a priori the transcendent status of a 'desire' of life as such, a 'pressure' to grow, to expand and, when this is no longer possible, to 'enter ebullition' (1991, 30). Life can never 'explode' for him because it is always already posited as One being, either growing or boiling. Bataille's general economy thus tacitly presupposes an underlying eternal 'construction' - the 'desire' of life as such - that sustains both growth and destruction.

\footnotetext{
${ }^{9}$ I have myself analysed in detail the way in which Lacan relates ethics to the maintenance of the Symbolic, see Chiesa (2007, especially 167-182).
} 
Bataille himself realises that gift-giving, even in the apparently non-profitable form of the potlatch, ultimately relies on a paradox. In his own words, 'gift-giving has the virtue of a surpassing of the subject who gives, but in exchange for the object given, the subject appropriates the surpassing', that is to say, 'he regards his virtue, that which he had the capacity for, as an asset, as a power that he now possesses' $(1991,69)$. By way of practices such as the potlatch, man places 'the value, the prestige and the truth of life in the negation of the servile use of possessions, but at the same time [he] makes a servile use of this negation' (1991, 73). However, Bataille does not acknowledge that this ambiguity of giftgiving is paralleled by another more crucial ambiguity, if not a contradiction, in his very notion of general economy - especially regarding its ethical implications - one which, in my opinion, he is not able to overcome - at least not in The Accursed Share.

More precisely, is the new ethics that Bataille has in mind an ethics that should only take into consideration general economy or does it coincide with an ethics of general economy tout-court? On the one hand, Bataille calls for a subjective stance able to practise 'acceptable' losses by way of gift-giving; these 'conscious' losses are 'preferable' insofar as they avoid catastrophic losses (Bataille 1991, 31). On the other hand, he also clearly suggests that 'the gift does not mean anything from the standpoint of general economy' $(1991,70)$. These statements produce an antinomy. Either the new ethics of 'controlled' destructions ultimately remains at the useful level of restrictive economy in spite of the fact that it takes into consideration general economy - and this is something Bataille denies; he refuses to acknowledge any compatibility between the new ethics and utility ('acceptable loss [is] a question of acceptability, not utility' (Bataille 1991, 31)). Or, he is promoting an ethics of general economy tout-court, in which case it is not clear to me why he should care about gift-giving in the first place. Whatever comes out of man's restrictive economy, including massive, uncontrolled destructions, is always already ultimately dependent on general economy and consequently should always be endorsed. In this case, the ethics of general economy would be nothing other than an ethics of fatalistic passive nihilism. Once again, I believe that the principal cause of this antinomy is Bataille's idea that general biological economy somehow transcendently contains restrictive human economy, that the 'living organism', life as One, precedes symbolic constructions.

In opposition to this stance, according to Lacan, the gift means everything from the standpoint of general economy; simply put, the gift 'saves' the symbolic order, considered

\footnotetext{
${ }^{10}$ This is the title of the first section of Part One of The Accursed Share.
} 
as general economy. For Lacan, the gift definitely transcends the restrictive servicing of the good: it is anti-utilitarian insofar as one does not expect any reciprocation. And yet, for this very reason - the fact that the symbolic structure as such needs lack and 'controlled destructions' in order to subsist - the gift is ultimately useful. General economy is strictly intertwined with restrictive economy: the latter is not merely a subset of the former, it does not follow it.

$X$

The common source of Lacan's and Bataille's elaborations on the potlatch is Marcel Mauss's seminal 1923 essay The Gift. Mauss himself effectively delineates the paradox of gift-giving and, like Lacan, emphasises its ultimate utilitarian aim: 'Even pure destruction of wealth does not signify that complete detachment that one might believe to be found in it' (1990, 74). During the potlatch one may 'even destroy for the pleasure of destroying', but this consumption 'is in no way disinterested'. Since giving is showing one's superiority and hence asserting one's power, 'through such gifts a hierarchy is established' $(1990,74)$. Elsewhere in the essay, an important footnote informs us that this is particularly the case in societies whose hierarchy is 'unstable' $(1990,97)$. The potlatch 'saves' the stability of the symbolic order through controlled destructions. However, in spite of its fundamentally conservative function, the potlatch could never be reduced to the logic of 'pure interest', which, according to Mauss, originated among Greek and Semitic populations and finds its most developed formulation in today's capitalism and its 'constant, icy, utilitarian calculations' $(1990,76)$.

Having said this, Mauss's sociological considerations about capitalism remain after all dangerously optimistic and thus have no bearing on Bataille's and Lacan's condemnation of the foreclusion of lack operated by the 'society of enterprise'. While Mauss warns us that 'it is not in the calculation of individual needs that the method for an optimum economy is to be found' $(1990,77)$, his demagogic social-democratic stance nonetheless makes him enthusiastically propose that 'the themes of the gift, of the freedom and the obligation inherent in the gift, of generosity [...] are reappearing in [...] society, as a dominant motif too long forgotten' $(1990,68)$. Mauss believes that the validity of this grand statement is sufficiently corroborated by a 'few new principles of [French] law' concerning 'social insurance', the 'family assistance funds', 'insurance against unemployment', and the 'right of succession' given to an artist and his inheritors 'over the series of additional gains made 
during the successive sales of [the artist's] work' $(1990,67)$. These are for Mauss all indications of the fact that 'a whole section of our law that is now emerging [...] consists of turning back the clock' and that 'this reaction [...] of our system is perfectly healthy and well founded' (1990, 66-67). Bearing in mind that The Gift was written in the year of Mussolini's March on Rome and Hitler's first attempt to gain power, Mauss's passionate call for a return to 'a group morality [...] honour, disinterestedness [and] corporate solidarity' (1990, 68-69) sound exceptionally dubious.

Leaving aside this matter, it is nevertheless the case that in the anthropological part of his essay Mauss offers us many interesting hints concerning the relation between gift-giving, the maintenance of the symbolic order, and violence which were not fully developed by Bataille's and Lacan's more philosophical elaborations. From the beginning, Mauss defines the potlatch as a 'total service of an agonistic type' $(1990,7)$ that mainly differs from other forms of gift-exchange in the violence it entails (Mauss 1990, 35); such violence goes as far as 'the killing of chiefs and nobles who confront each other' (1990, 6, my translation) in the potlatch. Some forms of gift-exchange require violence.

Furthermore, Mauss stresses that, even in the case of forms of gift-exchange that do not necessarily entail the use of violence, 'to refuse to give, to fail to invite, just as to refuse to accept is tantamount to declaring war; it is to reject the bond of alliance and commonality' (1990, 13). Similarly, retaining the gift for too long is dangerous and potentially fatal insofar as the gift itself contains a force capable of destroying those who have accepted it but fail to observe the obligation to reciprocate (Mauss 1990, 10). Acts of reparative violence against those members of a community who interrupt the dialectic of gift-exchange may also be carried out directly by other members of the same community. Mauss refers to a ritual in which such a reparative violence is commemorated by the Kwakiutl people. In the so-called Ceremony of the Dogs, a number of men masked as dogs force an entrance into a house: 'This commemorates the time when the people of the three other clans of the Kwakiutl tribe [...] omitted to invite the most high-ranking clan among them, the Guetala. The latter did not wish to remain "profane" and, entering the house where dances were going on, destroyed everything' (1990, 40-41).

Why does Moses, Dogville's prophetic dog, materialise only at the very end of the film after Grace has exterminated all Dogvillians? Why can't we see it even though we can hear it 
barking upon Grace's two arrivals ${ }^{11}$ - her first appearance in town as well as her forced return following her failed attempt to escape Dogville hidden in Ben's truck? Is it because the first two and a half hours of Dogville take place in a 'ultra-historic' time, the time that it takes for time to finish, considered both as the Messianic time of Christian Grace and the late-capitalistic biopolitical time that overcomes the dichotomy human/animal and thus literally renders the animal realm invisible for man? If this were the case, following Agamben on this point, aren't we allowed to suggest that we cannot see Moses because it is possible to separate animal life from human life only within man, and this separation is precisely what is revoked by the biopolitical animalisation of man? Yet, doesn't Dogville go a step further and brilliantly indicate the unresolved tension underlying Agamben's own work, namely the fact that the time of Messianic Christian Grace and that of biopolitics are one and the same insofar as they partake of an identical perverse sado-masochistic libidinal economy? And, most importantly, doesn't Dogville's finale depict a Ceremony of the Dog in the precise Kwakiutlan sense, a reparative violence that interrupts the interruption of the dialectic of gift-exchange and thus averts the apocalyptic disintegration of society as such?

Dogs appear to have an important function in Mauss's The Gift. he refers to them a second time in the context of his description of the kula, a Melanesian form of potlatch. Dogs are the protagonists of a formula of enchantment used by those associated in this ritual, whose function is to 'enumerate all that the kula proscribes, all the things relating to war that must be exorcised in order to be able to trade between friends'. This formula goes as follows: 'Your fury, the dog turns its nose up at it / Your paint of war, the dog turns its nose up at it, etc.' (Mauss 1990, 25). Or, in another version: 'Your fury takes off like the tide. The dog plays / Your anger takes off like the tide. The dog plays, etc'. Mauss suggests that this should be understood in the following way: 'Your fury becomes like the dog who is playing'. Malinowski's original interpretation of the formula is more detailed: 'The dogs are playfully nuzzling one another. When you mention this word "dog", the precious things also come to play [...]. We have given bracelets, necklaces will come'.

I think we should oppose diametrically this 'pretty parable', the image of the reciprocal sniffing of dogs considered as friends who exchange gifts, to the image of Grace being chained up like a dog and sexually abused in Dogville. Literally, Grace takes up the place of Moses, Dogville's invisible dog. The animalisation of man that replaces the

\footnotetext{
11 To quote the spell cast over the 'partner-candidate' of the kula by the Trobriand people, it is definitely the case that 'a state of excitement takes hold' of Dogville's dog...
} 
dichotomy man/animal is nothing else than the direct consequence of the 'entrepreneurial' logic of accumulation that perverts the gift-exchange, and perversely 'takes hold of man's belt'. As Dogville's narrator says: 'Since the chain had been attached things had become easier for everyone. The harassment in bed did not have to be kept secret anymore because it could not really be compared to a sexual act'; 'These acts were embarrassing, as it is when a hillbilly has his way with a cow, but not more than that'. GraceKidman is animalised by Dogvillians; and yet, insofar as she embodies Christian Grace, she fosters, or at least does not refuse, her humiliation. As she says right at the beginning of the film, holding Moses' bone in her hands, she deserves to be punished. We could well suggest that, paradoxically enough, Grace-Kidman consents to be raped. It is thus only her final act of purely subjective violence that allows Grace-Kidman to overcome her earlier allegorical embodiment of Christian Grace, and transform grace into something completely different.

\section{XII}

In one particular instance, Dogville's narrator's apparent omniscience seems to be refuted by his very own words. When Grace's Christian passion reaches its climax, he informs us that 'it was not pride that kept Grace surviving but the trance-like state that descends on animals whose life is threatened, a state in which the body reacts mechanically in a low, tough gear'. Grace is here reduced to what, with reference to his Auschwitz experience, Primo Levi calls a Muselmann. However, this statement is blatantly contradicted shortly after: 'The generous God had given Grace one gift; the gift of being able to look ahead, only ahead'. We must conclude that there are two kinds of grace after all. The film's finale can be interpreted correctly only if we take into consideration the oscillation between these two meanings of grace. The gift of Grace, as subjective genitive, is her ability to always look ahead, to start all over again, from scratch. The gift that the subject-Grace was endowed with must therefore be opposed to the sado-masochistic Christian gift of Grace, to be understood as objective genitive. The passage from the latter to the former can be accomplished only by way of an act of violence.

Once again, Dogville depicts a society in which the dialectic of gift-exchange has come to a halt due to a perverse will to accumulate. Grace-Kidman's final act overcomes this impasse through a unilateral reparative potlatch, following which the gift-exchange can start all over again. In spite of its unmercifulness, Grace's final act still lies within the domain of 'controlled' violence. Indeed, its ultimate objective is the preservation of the 
symbolic order as such, in opposition to the sado-masochistic tendency of the capitalistic discourse of the good that, as Lacan notes, ultimately leads us to 'the point of apocalypse' $(1992,207)$. If we wish to identify a positive objective dimension of the gift of Grace, we may well propose that the gift that the finally subjectivised Grace gives us all consists of saving society through 'controlled' violence. ${ }^{12}$

In a 1997 interview with Peter Hallward, Alain Badiou defines 'laicised grace' as that which raises man above his animality (in Badiou 2001, 133). He further specifies that grace is 'an evental giving, based absolutely on chance, and beyond any principle of the management or calculation of existence'. Grace offers us a 'chance of truth, a chance of being a little bit more than living individuals' (in Badiou 2001, 122-23, my emphases). Adopting Badiou's own terminology, we could thus further suggest that if Dogvillians reduce themselves and Grace-Kidman to animality in the name of the 'principle of management', this happens because they are not 'faithful' to her evental giving, or, in the narrator's own words, they are not able 'to look ahead'. (Let us leave aside here the fact that, as I have repeatedly pointed out, the unconditional giving of Christian Grace is itself problematic; let us suppose for a moment that Grace-Kidman is right from the beginning, a laicised gift of grace, what Badiou names an 'event'... ${ }^{13}$ )

\footnotetext{
12 Responding to my paper, Johan Schokker has argued that it is unnecessary to divide Grace into two kind of graces. 'This is my point: if you want to take seriously the act of Grace, as a subjectivised act, then you also have to take masochistic Grace seriously. If a subject is capable of such a radical act, he is also capable of radical forgiveness. [...] Radical Goodness exists, but in the end it is not different from radical Evil'. Schokker focuses on a dialogue between Grace and Chuck to illustrate his point: 'We are with Grace and Chuck in the apple garden [...] Chuck wants her and he tries to kiss her [...] but, well, Grace turns away. Chuck is a rejected lover: "Sorry, you made me so happy", he says, and wants to cry. But then Grace says: "I should ask you for forgiveness". What is this? How to understand this? In my reading, Grace knows perfectly well that Chuck passed the limits of friendship. There is a traumatic attempt to kiss her. But Grace is not saying: "You tried to rape me and, in my Goodness, I forgive you". No. Her response is more refined. She says: sorry that I misunderstood this friendly gesture as a sexual attempt. That is, she does not forgive Chuck explicitly for his act, which would mean that Chuck, while forgiven, would also be marked by his failed attempt. Grace knows perfectly well that Chuck tried to rape her, but she says: "I misjudged you". In other words: we know perfectly well that you tried to rape me, but let us say that it was just a friendly gesture that I misinterpreted; in this way we can still be friends as before and you are not guilty. So what is this act of forgiveness of Grace? "Being able to look ahead, and only ahead". The two Graces are One! The radical forgiveness of Grace is a continual attempt to wipe out what happened, it is the death drive which makes a new start possible, and this is the SAME Grace that destroys Dogville'. (Private communication).

${ }^{13}$ Dogville would have most probably acted in the same way even without Grace's 'fostering' of her passion. Given Tom's leadership, Dogvillians would have anyway attempted to recuperate her evental giving within the economy of the service of the goods...
} 
According to Badiou, a lack of fidelity can also be defined as a 'betrayal'. One betrays an event when one gives up on what Badiou calls the 'disinterested-interest' that makes a subject for the sake of one's 'ordinary interests', the human animal (Badiou 2001, 78); in other words, one betrays an event when one returns to the 'service of the goods' (Badiou 2001,80 ). Badiou goes as far as concluding that betrayal is nothing less that one of the forms of Evil as such. Following on this, we may suggest that if, on the one hand, Dogville is initially just a normal community of scoundrels, on the other hand, its treatment of Grace finally turns it into a paradigm of Evil as betrayal. The only social link that keeps Dogvillians together in the time that time takes to finish is its unanimous betrayal of Grace. The main street of Dogville, Elm Street - a reference both to a celebrated place of collective cinematic nightmares and to the thoroughfare in Dallas where President Kennedy was assassinated - is a street for serial-killers, not just scoundrels.

\section{XIV}

What should we do with traitors? This is a question that the relatively moderate political stance of Badiou's recent writings prefers to avoid altogether. However, the early Maoist Badiou of books such as Théorie de la contradiction and Théorie du sujet insisted on the following politico-philosophical maxim: 'It is right to rebel against the reactionaries'.

At what point in Dogville does Grace-Kidman herself adopt this view? I believe that Dogville's narrator perfectly summarises this key moment with the following words: 'Would Grace not have done the same as all other Dogvillians? No, if she had acted like them, she could not have defended a single one of their actions'. The crucial idea we should grasp here in order to interpret the film's finale correctly is that it is only at this stage that Grace is able to answer 'No!'... Throughout her passion she invariably answered 'Yes!', and that was her arrogant forgiveness. The subject-Grace decides to exterminate all Dogvillians when she realises that their reactionary betrayal - their foreclosure of the gift as lack - is an unforgivable evil, against which one must rebel. ${ }^{14}$ In doing so, she overcomes her earlier masochistic forgiveness, that is, Christian Grace.

From a Lacanian standpoint, we could propose that it is only after Grace answers 'No!' to the aforementioned question that she traverses her fundamental fantasy. Initially,

\footnotetext{
${ }^{14}$ Note that Grace realises this before discussing with her father. 
we see how the protagonist's tragic 'No!' to her gangster-Father ${ }^{15}$ and his life-style unexpectedly goes hand in hand with her becoming the sacrificial object of the Other, the town of Dogville. ${ }^{16}$ The protagonist traverses her fundamental fantasy only later on, when she sacrifices her own sacrificial fantasy, her being the object of the Other's enjoyment, precisely by exterminating all the inhabitants of Dogville (the moment of subtraction) and by establishing a new Master-Signifier (the moment of symbolic re-inscription; what in the film Grace herself calls 'assuming power'). In other words, Dogville shows us how the most fundamental fantasy to be traversed is, in the end, the one in which the tragic fantasy of an inflexible 'No!' to the existing Father/Master/Other becomes indistinguishable from the perverse fantasy in which the subject sacrifices himself for another allegedly alternative Other.

\section{XV}

Isn't the film's finale a perfect example of what is at stake with the notion of active nihilism? In this sense, we could well regard it as a worthy spiritual heir to Brecht and Weill's song Pirate Jenny, Lars von Trier's main source of inspiration for Dogville. (As Grace says, quoting Jenny, if things are pushed too far, 'nobody is gonna sleep here tonight, nobody'.) It would definitely be wrong to confuse active nihilism, revolution, with passive nihilism, the apocalypse. In the last chapter of Théorie du sujet, Badiou defines active nihilism as 'inapplicable confidence' (Badiou 2005: 655), this is what the gift of Grace-Kidman is all about, 'inapplicable confidence', being capable of 'always looking ahead'. According to Badiou, 'the essence of confidence lies in having confidence in confidence' and 'this is why it is right to revolt' $(2005,652)$. Badiou then proceeds to offer a very convincing characterization of the active nihilist, with which I would like to conclude my essay. In relating it to Dogville, please bear in mind two things. First, Grace-Kidman is a 'traveler without luggage' and Lars von Trier repeatedly invited his audience to consider Dogville as a metaphor for the current debate about immigration (in Luhmoldt 2003, 209). Second, Grace-the-immigrant risks succumbing to the 'most rancid products' of Christian religion.

\footnotetext{
${ }^{15} \mathrm{~A}$ perfect exemplification of the fact that the Father is always - or, better, is always thought to be an obscene jouisseur, not only an agent of prohibition...

${ }^{16}$ This is a perfectly Lacanian-Žižekian lesson. Saying 'No!' to the Father - opposing the Oedipus with an only supposedly emancipative Anti-Oedipus - is not, as such, a sufficient guarantee that one will avoid different and more perverse forms of subjection/enslavement.
}

Chiesa, Lorenzo (2007) 'What is the Gift of Grace? On Dogville', Film-Philosophy, vol. 11, no. 3: 
Vigorous active nihilism is in search of a form of confidence and, if we no longer convey one to it directly, we can [only] wait with... confidence. [...] Active nihilism valorizes only itself. This is always better than to end up tolerating the world. [...] The active nihilist inherits nothing. He never believed, and there lies all his strength. Unless he joins religious sects, through which he will leap to the most rancid products of belief, he is a traveler without luggage, whose only future is courage. (Badiou 2005, 655)

\section{Acknowledgements}

A preliminary version of this article was originally delivered at the International conference 'A Community of Scoundrels: The Gift in Modern Society through Lars Von Trier's Dogville', University of Nijmegen (18-19 May 2005).

\section{Bibliography}

Agamben, Giorgio (2005) The Time That Remains. Stanford: Stanford University Press.

Badiou, Alain (2001) Ethics: An Essay on the Understanding of Evil. London: Verso.

Badiou, Alain (2005) 'Further Selections from Théorie du sujet', Positions 13.3, special issue Alain Badiou and Cultural Revolution: 649-658.

Baladier, Charles (2003) 'À propos de Dogville "Grâce"', Oedipe.org. http://www.oedipe.org/fr/spectacle/grace

Bataille, Georges (1991) The Accursed Share, Volume I. New York: Zone Books.

Bjorkman, Stig (ed.) (2004) Trier on von Trier. London: Faber \& Faber.

Chiesa, Lorenzo (2007) Subjectivity and Otherness: A Philosophical Reading of Lacan. Cambridge MA: MIT Press.

De Kesel, Marc (2004) 'De hondin van het dorp. Over Lars von Triers Dogville', De Witte Raaf 107: 11-15.

Lacan, Jacques (1992) The Seminar. Book VII. The Ethics of Psychoanalysis, 1959-1960. London: Routledge.

Lacan, Jacques (1994) Le séminaire livre IV. La relation d'objet, 1956-1957. Paris: Seuil.

Lumholdt, Jan (ed.) (2003) Lars von Trier: Interviews. Jackson: University Press of Mississippi.

Mauss, Marcel (1990) The Gift. London: Routledge.

Pasolini, Pier Paolo (1992) Petrolio. Turin: Einaudi.

Trier, Lars von (n.d.) 'About Dogville', Dogville Official Web Site. 
http://www.electricparc.com/webdesign/dogville/

\section{Filmography}

Trier, Lars Von (2003) Dogville, Denmark. 
http://www.electricparc.com/webdesign/dogville/

\section{Filmography}

Trier, Lars Von (2003) Dogville, Denmark. 